\title{
Social skills inventory for adolescents: evidence of construct validity and reliability
}

\author{
Vanessa Barbosa Romera Leme \\ Universidade do Estado do Rio de Janeiro, RJ, Brasil \\ Josiane Rosa Campos \\ Universidade Estadual Paulista “Júlio de Mesquita Filho”, SP, Brasil \\ Susana Coimbra \\ Universidade do Porto, Portugal \\ Almir Del Prette \\ Zilda Aparecida Pereira Del Prette \\ Universidade Federal de São Carlos, SP, Brasil
}

\begin{abstract}
Social skills are considered as an important indicator of social and emotional development. In the Brazilian context, the Social Skills Inventory for Adolescents (IHSA-Del-Prette) is available for the assessment of this repertoire, and is widely used in research and intervention. Favorable psychometric properties have been established through Principle Components Analysis (PCA). The present study aimed to compare the structure established through PCA with that established through Exploratory Factor Analysis (EFA) and to verify the indicators of validity and reliability produced by Confirmatory Factor Analysis (CFA). A total of 2291 students of $6^{\text {th }}, 7^{\text {th }}$ and $8^{\text {th }}$ years of Elementary Education and $1^{\text {st }}$ and $2^{\text {nd }}$ years of High School Education participated. The results showed a factorial structure very similar to that originally produced with PCA, with six oblique factors confirmed through CFA and with suitable indicators of reliability. The IHSA-Del-Prette presented psychometric qualities that recommend indicate its use in the Brazilian context.
\end{abstract}

Keywords: Social skills; Adolescence; Factor analysis; Reliability.

\section{Inventário de habilidades sociais para adolescentes: evidências de validade de constructo e confiabilidade}

\section{Resumo}

As habilidades sociais têm sido tomadas como um importante indicador de desenvolvimento social e emocional. Para avaliação desse repertório, tem-se, no contexto brasileiro, o Inventário de Habilidades Sociais para Adolescentes (IHSA-Del-Prette). Esse instrumento de medida é amplamente utilizado na investigação e intervenção, com propriedades psicométricas favoráveis obtidas por Análise de Componentes Principais (ACP). Este estudo visa comparar a estrutura obtida por ACP à obtida por Análise Fatorial Exploratória (AFE) e verificar os indicadores de validade e confiabilidade produzidos por Análise Fatorial Confirmatória (AFC).

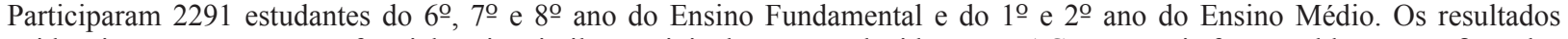
evidenciaram uma estrutura fatorial muito similar à originalmente produzida com a ACP, com seis fatores oblíquos confirmados pela AFC e com indicadores adequados de confiabilidade. Conclui-se que o IHSA-Del-Prette apresenta qualidades psicométricas que o recomendam para uso no contexto brasileiro.

Palavras-chave: Habilidades sociais; Adolescência; Análise fatorial; Confiabilidade.

\section{Inventario de habilidades sociales para adolescentes: evidencia de validez de constructo y confiabilidad}

\begin{abstract}
Resumen
Las habilidades sociales se han tomado como indicador del desarrollo social y emocional. Para revisar este repertorio, tiene, en el contexto brasileño, el Inventario de Habilidades Sociales para adolescentes (IHSA-Del-Prette). Este instrumento de medición es ampliamente utilizado en la investigación y la intervención, con propiedades psicométricas favorables obtenidos por Análisis de Componentes Principales (ACP). Este estudio tiene como objetivo comparar la estructura obtenida mediante ACP obtenido por el Análisis Factorial Exploratorio (AFE) y verificar la validez y fiabilidad de los indicadores producidos por el Análisis Factorial Confirmatorio (AFC). Participaron 2291 estudiantes de $6^{\circ}$, $7^{\circ}$ y y $8^{\circ}$ año de la escuela primaria y el $1^{\mathrm{O}}$ y $2^{\mathrm{O}}$ año de secundaria. Los resultados mostraron una estructura factorial muy similar al producido originalmente por el ACP, con seis factores oblicuos confirmados por la AFC, y con indicadores adecuados de fiabilidad. Llegamos a la conclusión de que la IHSA-Del-Prette presenta cualidades psicométricas de recomendable para su uso en nuestro contexto.
\end{abstract}

Palabras clave: Habilidades Sociales; Adolescencia; Analisis Explotario; Fiabilidad. 


\section{Introduction}

The literature extensively demonstrates positive correlations between a good social skills repertoire in adolescence and positive outcomes such as quality of life, health, social-emotional development, and prospects for professional success and psychosocial adjustment. Negative correlations with behavior problems, psychological disorders, aggression, and other adjustment difficulties are also highlighted (Barkin, Smith, \& Durant, 2002; Del Prette, Falcone, \& Murta, 2013; Fraser \& Williams, 2004; GoldbergLillehoj, Spoth, \& Trudeau, 2005). According to Del Prette and Del Prette (2005), deficits in social skills may be part and/or effect of the symptomology of psychological disorders and can constitute warning signs of possible problems in later stages of development. Psychological resilience research results point out the importance of both, social skills and social competence, in particular during the developmental phases that immediately precede and succeed the transition to adulthood (Obradovic, Burt, \& Masten, 2010; Masten \& Tellegen, 2012).

As explained by Del Prette and Del Prette (2001) and Del Prette and Del Prette (2005; 2010/2012), social skills and social competence are distinct constructs, although they are linked in the analysis of social performance: the term social skills is descriptive of the classes of learned social behaviors available in the repertoire of the individual; social competence is an evaluative attribute of performance, based on its functions (instrumental and ethical) and on the coherence with the thoughts and feelings of the individual (Del Prette \& Del Prette, 2001; 2010/2012). According to these authors, an elaborate social skills repertoire can be considered a necessary although insufficient condition for social competence. In fact, other competing factors, such as beliefs, values, plans, and goals, may affect the social performance. These authors emphasize the role of culture on the social skills, since it defines the patterns expected and valued on different contexts or roles, taking into account demographic characteristics, such as age, gender or social roles.

To monitor the social skills repertoire in adolescence is important in order to prevent psychopathology and to promote the promotion of mental health (Del Prette \& Del Prette, 2006; Del Prette et al., 2013), in particular within those groups who are exposed to significant risk (Del Prette \& Del Prette, 2009), such as: negative parenting practices of physical punishment, neglect and psychological threats (Salvo, 2010); mothers and fathers with psychopathologies such as depression and consequent difficulty in educating their children (Goodman et al., 2010); friendships with deviant peers (Salvo, 2010); use and abuse of substances and increased conflicts with parents and feelings of loneliness (Barbosa Filho, Campos, \& Lopes, 2012); violent partners (Murta, Santos, Martins, \& Oliveira, 2013); low academic performance (D'Abreu \& Marturano, 2010) or even difficulty in initiating and maintaining friendships (Gresham, Cook, Crews, \& Kern, 2004).

Exposure to these conditions increases the likelihood of the emergence of internalizing (depression, anxiety and withdrawal) and externalizing (breaking rules, aggression, agitation) behavior problems for the adolescent, having both a high prevalence within adolescent population (Achenbach \& Rescorla, 2001; Rocha, 2012). Therefore, as highlighted in the metaanalysis by Durlak, Weissberg and Pachan (2010), acquiring a socially skilled and socially competent repertoire can prevent, alleviate or reduce existing behavioral problems. For example, self-control and feelings expression make it more likely to effective problem solving and decision making. Chen (2006), in his literature review on the acquisition of social skills by young people, highlighted that social skills help to develop behavioral patterns that contribute to the development of positive relationships, better academic performance, more satisfactory family relationships and with peers, leading therefore to more social acceptance and less exclusion.

Taking into consideration the above, it is essential to have precise and valid instruments, which can be used to develop effective interventions in this area. The Social Skills Inventory for Adolescents was recently developed in Brazil (IHSA-Del-Prette, Del Prette \& Del Prette, 2009). This instrument has already approved by the Federal Psychology Council and is provided with reference standards. In addition to the favorable psychometric properties, described in the IHSA-Del-Prette Manual, some studies have already evidenced other indicators of its criterion validity (Del Prette, Rocha, Silvares, \& Del Prette, 2012), as well as additional indicators of reliability and convergent validity (Del Prette, Teodoro, \& Del Prette, 2014).

The quality of psychological assessment instruments represents a process that must be continually reevaluated based on new indicators and for each sample (Anastasi \& Urbina, 1997). The initial construct validation study of the IHSA-Del-Prette (Del Prette \& Del Prette, 2009) produced satisfactory results regarding the percentage of explained variance of the scales (from $40 \%$ to $62 \%$ ) and items with adequate factor loadings (greater than 0.40). However, the initial structure was strictly based 
on Principal Component Analysis (PCA) which has been considered as a preliminary but not sufficient method for the construct validation of psychological instruments (Tabachnick \& Fidell, 2007), specially for further confirmatory analysis of its factorial structure. Alternatively, the Exploratory Factor Analysis (EFA) is more appropriate, not only due to its emphasis on the covariance or commonality of the variables, excluding the specific variance and error variance (Tabachnick \& Fidell, 2007), but also because it produces factors, assumed to be the hypothetical "causes" of the correlations between the variables. Principal Component Analysis groups the items but does not associate them with the factors, a procedure which is necessary to perform the Confirmatory Factor Analysis (CFA) for new samples. Obtaining indicators of fit for a factorial structure to new samples, through CFA, is important in the validation of psychological tests due to ratifying the theorization inherent to the factors and the empirical validity of this structure (Pilati \& Laros, 2007).

Considering that, in Brazil, the IHSA-Del-Prette is the only available scale to evaluate the adolescent needs and deficits for social skills training and to evaluate preventive and therapeutic programs aimed to improve this repertoire. Therefore, this instrument is widely used in research and intervention, which makes it crucial to monitor its psychometric properties. Based on the above considerations, this study aimed: (a) to compare the original subscale structure of the IHSADel-Prette, obtained through PCA in the original study (IHSA-Del-Prette-Manual), with that obtained through Exploratory Factor Analysis (EFA), using the same sample; (b) to confirm, through CFA, the structure previously produced through EFA; (c) to present internal consistency indicators of the factors obtained through EFA and CFA.

\section{Method}

\section{Sample}

The study consisted of three convenience samples collected over a five year period. The first sample was used in the initial validation of the IHSA-Del-Prette, described in its manual, using PCA at that time. In the original validation, Del Prette and Del Prette (2009) administered the instrument to 1172 adolescents (aged 12 to 17 years, $M=14.56 ; S D=1.65$ ) of both genders $(50.3 \%$ female). The students were attending the $5^{\text {th }}(\mathrm{n}=10,0.9 \%), 6^{\text {th }}(\mathrm{n}=176,15.0 \%), 7^{\text {th }}(\mathrm{n}=212$, $18.1 \%)$ and $8^{\text {th }}$ years $(n=164,14.0 \%)$ of Elementary Education and $1^{\text {st }}(n=252,21.5 \%), 2^{\text {nd }}(n=217$, $18.5 \%)$ and $3^{\text {rd }}$ years $(n=141,12.0 \%)$ of High School Education in public and private schools of different cities of the states of São Paulo, Minas Gerais and Paraná. Regarding socioeconomic status ${ }^{1}$, the highest proportion of students were concentrated in the $\mathrm{C}$ $(25.1 \%), \mathrm{B} 2(22.8 \%)$ and B1 (19.5\%) classes.

The second and third samples (referred from now on as IHSA-Del-Prette-Conf) were taken from two studies conducted with adolescents. The first study (Campos, 2014) collected data with 642 adolescents, and the second (Leme, 2013) involved 477 adolescents. Thus the IHSA-Del-Prette-Conf total sample was composed of 1119 students, being $51.9 \%$ (581) female and with ages between 12 and 17 years $(M=14.11, S D=1.31)$. The adolescents were attending the $6^{\text {th }}(\mathrm{n}=138,12.3 \%)$, $7^{\text {th }}(n=318,28.4 \%)$ and $8^{\text {th }}$ years $(n=186,16.6 \%)$ of Elementary Education and the $1^{\text {st }}(n=309,27.6 \%)$ and $2^{\text {nd }}(n=168,15.0 \%)$ years of High School Education of public schools of two medium sized cities of the states of São Paulo and Minas Gerais. Regarding the socioeconomic level, the highest proportion of students were concentrated in the C (24.3\%), B2 (38.4\%) and B1 (27.1\%) classes.

\section{Instruments}

Social Skills Inventory for Adolescents (IHSA-DelPrette). This self-reported instrument was developed by Del Prette and Del Prette (2009) and assesses the social skills of adolescents based on everyday situations of social interaction. It comprises thirty eight items which are divided six subscales skills: (1) Empathy (e.g., "When I notice that a colleague is sad or in trouble, I offer them my support"); (2) Selfcontrol (e.g., "I react calmly when things do not go as I would like"); (3) Civility (e.g., "When someone does something good, I praise them"); (4) Assertiveness (e.g., "When a person makes a request that I find improper, I refuse"); (5) Affective Approach (e.g., "If I do not want to date a boy/girl, I refuse, even if he/ she is very insistent"); and (6) Social Resourcefulness (e.g., "At school or in my job, I make oral presentations in groups when requested"). The items are rated on five points Likert type scale: $0=$ " $0-2$ times, $1=$ " $3-4$ times", $2=" 5-6$ times", $4=$ "7-8 times", $5=$ "9-10 times". In the original validation, Del Prette and Del Prette (2009), using CPA, suitable internal consistency indices for the frequency subscales were encountered: Empathy: $\alpha=0.82$; Self-control: $\alpha=0.73$; Civility: $\alpha=0.75$; Assertiveness: $\alpha=0.68$; Affective Approach: $\alpha=0.70$; Social Resourcefulness $\alpha=0.61$. The temporal stability

\footnotetext{
In this study the evaluation of the socioeconomic level of the population was performed using the Critério Brasil (ABEP, 2011 - http://www.abep. org/criterioBrasil.aspx) which identifies five classes based on education level and purchasing power, these being, from highest to lowest: A (divided into $\mathrm{A} 1$ and $\mathrm{A} 2$ ), B (divided into B1 and B2), C, D and E.
} 
analysis indicated positive, high and significant testretest correlations $(r=0.84 ; p<0.001)$.

\section{Procedure}

Data were collected in three projects, approved by the Research Ethics Committee of the University where the survey was conducted (Authorization No. 23112.001179 - CAAE 0076.0.135.000-11; Authorization No. 23112.001163/2009-24 - CAAE 0735.0.000135-09 and Authorization No. 206/2005 CAAE 0086.1.135.000-05).

\section{Data Collection}

Data collection followed the same procedure in the three studies. This was performed collectively in the classrooms of the schools of the adolescents, at a time arranged by the teachers, when the terms of consent forms, signed by the person legally responsible for the student, were returned. At the beginning of each application, the aim of the study was presented, and guarantees regarding data confidentiality were given, reiterating that participation in the research was voluntary. The researchers remained in the classroom throughout the application of the instruments answering to possible questions, which lasted for an average of 30 minutes.

\section{Data Analysis}

Data were entered into the SPSS 18.0 program. First, the analysis of the missing data was performed through the Expectation-maximization method (EM). Next, the diagnosis of the multivariate outliers was made through the Mahalanobis distance $\left(\mathrm{D}^{2}\right)(p 1$ and $p 2$ $<0.001$ ) according to Marôco (2010), and the normality of the variables verified through the coefficients of skewness (sk) and kurtosis (ku), with values of $\mid$ sk $\mid>3$ indicators of severe asymmetry, and values of $|\mathrm{ku}|>10$ indicators of severe kurtosis (Kline, 2011). Finally, the existence of multicollinearity was analyzed through the verification of the correlation tables of items with values greater than 0.90 , with their suppression being indicated (Marôco, 2010).

For the Exploratory Factor Analysis (EFA), with the Principal Axis Factoring method, the original validation sample of the IHSA-Del-Prette-Manual were used. Factorial validity was determined based on Confirmatory Factor Analysis (CFA) using the Amos 18.0 program. The parameters were estimated based on the correlation matrix, using the robust maximum likelihood extraction method. Following the recommendations of Kline (2011) and Schweizer (2010), the overall fit of the hypothesized model was evaluated based on the following set of indices and their reference values for an acceptable fit: ratio $\chi^{2} / g .1$. $<5$ (Arbuckle, 2008); Bentler Comparative Fit Index - CFI > 0.90 (Hu \& Bentler, 1999), Root Mean Square Error of Approximation - RMSEA $<0.08$ (Arbuckle, 2008) and Standardized Root Mean Square Residual - SRMR $<0.10$ (Hu \& Bentler, 1999). The quality of the local fit was evaluated based on standardized factor loadings and the individual coefficients of reliability of the items, considering values higher than 0.50 and 0.25 , respectively, to be indicators of a good fit and, consequently, confirmation of the factorial validity of the model (Marôco, 2010).

The reliability of the IHSA-Del-Prette was assessed using Cronbach's alpha, considering a value over 0.70 to be a good level of consistency (Anastasi \& Urbina, 1997), and Composite Reliability (CR) that is obtained for each factor by dividing the square of the sum of the standardized factor loadings by this value plus the sum of the errors or residues of each item. Values above 0.70 were considered to be indicative of good construct reliability (Marôco, 2010).

\section{Results}

\section{Exploratory Factor Analysis of the IHSA-Del- Prette: Structure and Reliability}

The adequacy of the sample to the PAF (Principal Axis Factoring) was verified using the Kaiser-MeyerOlkin index $(\mathrm{KMO}=0.992)$ and Bartlett's sphericity test $\left(\chi^{2}=9717.621 ; d f=630 ; p=0.001\right)$, which indicated that factor analysis was strongly recommended (Tabachnick \& Fidell, 2007). The 38 items of the original instrument were submitted to PROMAX rotation (oblique), considering that factors are expected to be related to each other (Sass \& Schmitt, 2010) and taking an eigenvalue value higher than 1 as the factor extraction criterion. For the selection of the items, commonalities and saturations higher than 0.30 were considered (Worthington \& Whittaker, 2006).

The analysis revealed a factor structure very similar to that originally produced using PCA, with six factors, however, showing two differences: some changes in the order of some items within the factors; exclusion of items 6 ("When an opportunity arises, I do small favors, such as offering my chair or opening the door for someone, without being asked" from Civility factor) and 36 ("In relation to affection, at any time, I frankly say what displeases me" from Affective Approach factor). The factor structure resulted in 36 items distributed within six factors that presented factor loadings above 0.30 , with eigenvalues between 1.17 and 7.92, and with a total explained variance of $33.28 \%$. Because items 7 and 35 scored in more than 
one factor (Empathy and Civility factors; Empathy and Affective Approach factors, respectively), following the suggestions of Sass and Schmitt (2010), the selection of these items was made using the value of greater commonality in the factor as the criterion.
The analysis of internal consistency, based on Cronbach's Alpha coefficient, produced reasonable values in the six factors of the IHSA-Del-PretteManual ranging between 0.61 and 0.80 , and $\alpha=0.89$ for the Overall Score.

TABLE 1

Factor loadings of the items of the IHSA-Del-Prette-Manual (N=1172) obtained through the Principal Axis Factoring method, descriptive statistics, and reliability indicators

\begin{tabular}{|c|c|c|c|c|c|c|}
\hline \multirow{2}{*}{ Item } & \multicolumn{6}{|c|}{ Factor } \\
\hline & $E M P$ & $S C T$ & $C I V$ & $A S S$ & $A F T$ & SOC \\
\hline IHSA - 31 & .771 & & & & & \\
\hline IHSA - 34 & .640 & & & & & \\
\hline IHSA -28 & .553 & & & & & \\
\hline IHSA -26 & .542 & & & & & \\
\hline IHSA - 29 & .458 & & & & & \\
\hline IHSA - 32 & .435 & & & & & \\
\hline IHSA -24 & .413 & & & & & \\
\hline IHSA -30 & & .643 & & & & \\
\hline IHSA -38 & & .554 & & & & \\
\hline IHSA - 14 & & .518 & & & & \\
\hline IHSA - 8 & & .468 & & & & \\
\hline IHSA -22 & & .463 & & & & \\
\hline IHSA -33 & & .431 & & & & \\
\hline IHSA - 5 & & .352 & & & & \\
\hline IHSA -18 & & .308 & & & & \\
\hline IHSA - 4 & & & .795 & & & \\
\hline IHSA - 2 & & & .617 & & & \\
\hline IHSA - 3 & & & .602 & & & \\
\hline IHSA - 9 & & & .437 & & & \\
\hline IHSA -7 & .318 & & .414 & & & \\
\hline IHSA -15 & & & & .509 & & \\
\hline IHSA -23 & & & & .503 & & \\
\hline IHSA -12 & & & & .494 & & \\
\hline IHSA -27 & & & & .419 & & \\
\hline IHSA - 11 & & & & .332 & & \\
\hline IHSA - 16 & & & & .317 & & \\
\hline IHSA - 37 & & & & & .613 & \\
\hline IHSA -10 & & & & & .536 & \\
\hline IHSA -35 & .327 & & & & .488 & \\
\hline IHSA -13 & & & & & .468 & \\
\hline IHSA -25 & & & & & .404 & \\
\hline IHSA -20 & & & & & & .569 \\
\hline IHSA - 19 & & & & & & .506 \\
\hline IHSA -17 & & & & & & .336 \\
\hline IHSA - 21 & & & & & & .321 \\
\hline IHSA - 1 & & & & & & .304 \\
\hline Number of items & 7 & 8 & 5 & 6 & 5 & 5 \\
\hline Eigenvalues & 7.92 & 2.30 & 1.69 & 1.44 & 1.36 & 1.17 \\
\hline$\%$ Explained variance & 20.24 & 4.56 & 2.87 & 2.33 & 1.91 & 1.34 \\
\hline Mean (SD) & $20.83(5.43)$ & $17.09(6.04)$ & $15.76(3.92)$ & $16.47(4.73)$ & $10.04(4.40)$ & $11.46(4.26)$ \\
\hline Cronbach's Alfa & 0.80 & 0.73 & 0.75 & 0.63 & 0.68 & 0.61 \\
\hline
\end{tabular}

$\mathrm{IHSA}=$ Social Skills Inventory for Adolescents, EMP=Empathy, $\mathrm{SCT}=$ Self-Control, CIV=Civility, ASS = Assertiveness, AFT=Affective Approach, $\mathrm{SOC}=$ Social Resourcefulness, $\mathrm{SD}=$ Standard Deviation. 


\section{Confirmatory Factor Analysis of the IHSA-Del-Prette: Structure and Reliability}

Prior to performing the CFA, examination of the multivariate outliers (Mahalanobis distance, $\mathrm{D}^{2}$ ) was conducted. A total of 50 outlier observations were found, and a new CFA was performed without them. As the results did not differ from those obtained previously, the choice was made to maintain them in the sample, as suggested by Marôco (2010). The absence of multicollinearity and the psychometric sensitivity of the items of the IHSADel-Prette-Conf, analyzed from the distribution of the values of skewness and kurtosis, showed no marked difference from normal distribution (Kline, 2011).

Figure 1 presents the Confirmatory Factor Analysis of the IHSA-Del-Prette-Conf for the sample of adolescents. In the identification of the model, it was specified that each item of the IHSA-Del-Prette belonged to a single factor without cross saturation (according to the CFA), and that the measurement errors were not correlated. The correlation between the six factors was freely estimated.

The testing of the model, with six oblique factors of the IHSA-Del-Prette-Conf, presented acceptable indices and a good overall fit: $\chi^{2} / d f=2.84 ; \mathrm{CFI}=0.90$; $\mathrm{RMSEA}=0.04$; SRMR $=0.04$ ), with no need for respecification of the model, with its theoretical fit being prioritized. All the estimated parameters remained statistically significant $(p<0.001)$. Regarding the local fit, with the exception of items 8 and 38 (Self-control), 27 (Assertiveness), 10 (Affective Approach), and 17 (Social Resourcefulness), items had factor loadings and individual reliability coefficients higher than 0.50 and 0.25 respectively.

Suitable internal consistency values were verified for the factors and the overall score of the IHSA-DelPrette-Manual, confirming the reliability established in the validation study of Del Prette and Del Prette (2009): Empathy: $\alpha=0.82$; Self-control: $\alpha=0.75$; Civility: $\alpha=0.78$; Assertiveness: $\alpha=0.74$; Affective Approach: $\alpha=0.71$; Social Resourcefulness: $\alpha=0.68$. The factors obtained with the IHSA-Del-Prette-Conf sample also presented good Composite Reliability (Empathy: $\mathrm{CR}=0.82$; Self-control: $\mathrm{CR}=0.76$; Civility $\mathrm{CR}=0.79$; Assertiveness $\mathrm{CR}=0.70$; Affective Approach $\mathrm{CR}=0.71$; Social Resourcefulness $\mathrm{CR}=0.70$ ).

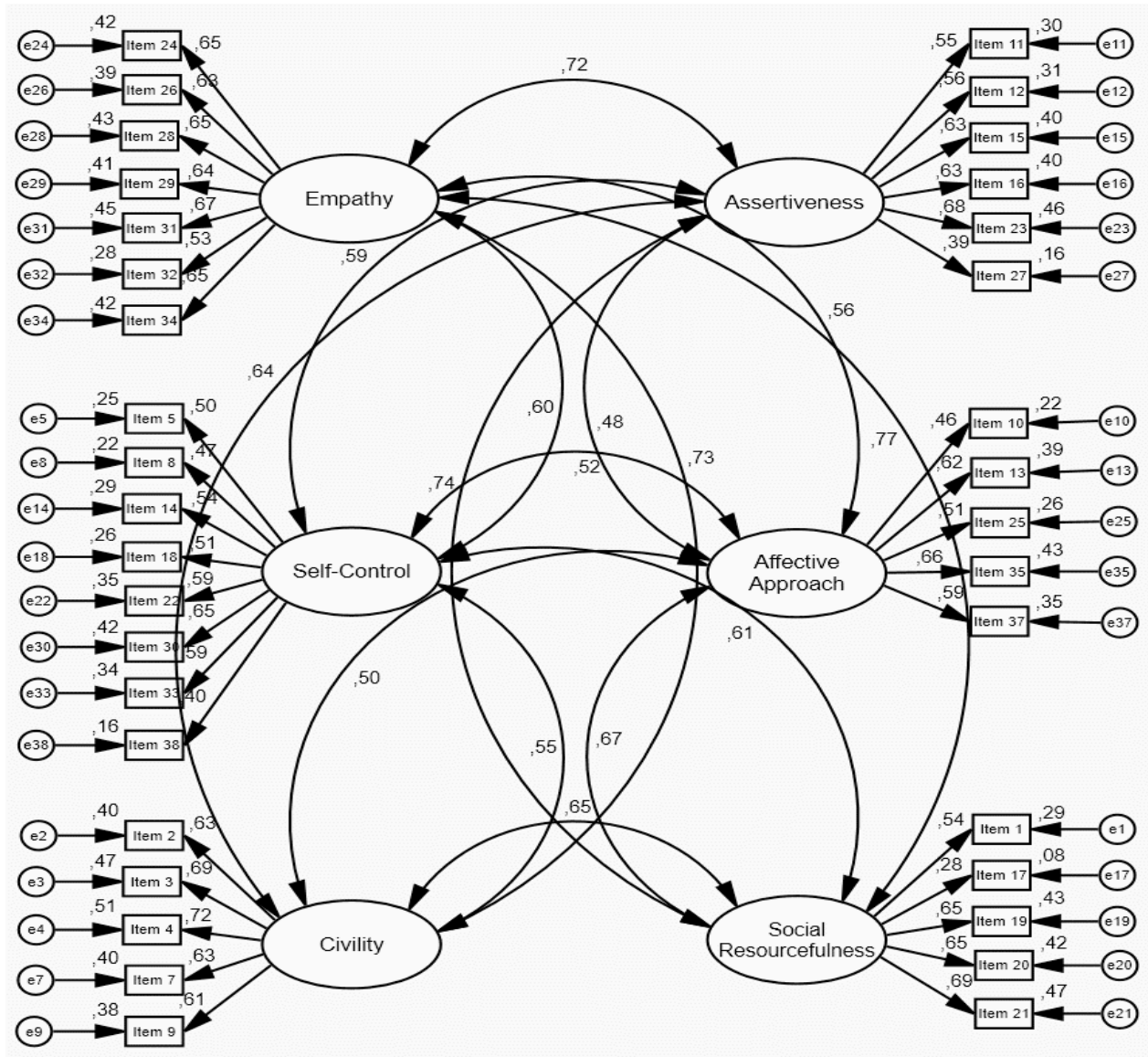

Figure 1. Confirmatory Factor Analysis of the Social Skills Inventory for Adolescents (IHSA-Del-Prette-Conf, N=1119) 


\section{Discussion}

The self-report inventories are widely used by practitioners and researchers, not only due to their simplicity and ease, but because they allow a normative and intra-individual analysis of the repertoire of any individual. The process of validation of a specific psychological measure is always an ongoing process that should be accurately described in order to guarantee its quality and adequacy to the populations they were designed to. It is then important to constantly update information regarding the accuracy of the measurement and demonstration of reliability to relevant population in order to avoid decisions on selecting tests that rely solely on face value or on test-users testimonials (ITC, 2014). Considering the social skills inventories, in the first case, the aim is usually to compare the results from one individual with a standard reference sample, to identify his/her resources and deficits; in the second, the aim is to analyze relationships between subsets of social skills and their possible relationships with processes, such as self-awareness, self-esteem, cognitive schemas etc. (Caballo, Del Prette, Monjas, \& Carrillo, 2006). In case of preventive and therapeutic interventions, a valid and reliable measure is indispensable to check the effectiveness of social skills programs as well as to identify and to improve their critical ingredients.

Over the last few years, Brazilian researchers and practitioners had only the IHSA -Del-Prette scale to evaluate the repertoire of social skills of adolescents. Although recommended by the Federal Council of Psychology, this scale was validated only by the method of Principal Component Analysis. Thus, the items were grouped into components, and not on factors such as derived from factor analysis. This prevented from checking its validity for new samples, which is usually done by the method of Factor Confirmatory Analysis. Considering this situation, the present study aimed to re-evaluate the construct validity and reliability of the Social Skills Inventory for Adolescents (IHSADel-Prette), both by Exploratory Factor Analysis and Confirmatory Factor Analysis.

At the first moment, the comparison between the initial structure, based on PCA, and the structure obtained in this study, based on EFA suggest the stability of the factorial structure it was verified that considering the substantial overlapping between the factors. This suggests that the theoretical model proposed for the social skills with adolescents was confirmed: interrelated items that satisfactorily explain the latent constructs investigated in each factor (Marôco, 2010; Pilati \& Laros, 2007). However, it can be seen that the explained variance was smaller $(33.28 \%)$ than the desirable $(>50 \%)$, although similar to some other psychological scales. The internal consistency of the Empathy, Assertiveness and Affective Approach factors were slightly smaller than those originally obtained by the PCA, what is common when comparing PCA and EFA. Anyway, these results suggest that the theoretical model proposed for the social skills with adolescents was confirmed, with inter-related items that satisfactorily explain the latent constructs investigated in each factor (Marôco, 2010; Pilati \& Laros, 2007).

Further evidence for these assumptions was found by the CFA: the theoretical model of the IHSADel-Prette, with six oblique factors, presented a satisfactory local and global fit, thus suggesting a fit of the inventory with the data of the sample ( $\mathrm{Hu} \&$ Bentler, 1999; Kline 2011; Schweizer, 2010). It was considered that the factor loadings of two items $(0.47$ for item 8 and 0.46 for item 10) did not invalidate the factorial validity of the instrument, especially considering that the other overall indicators of the scale were acceptable (Figure 1).

Some possible explanations may be raised for the lower loading values observed in the case of three of the items $(38,27$ and 17). In relation to items $27-I$ show my annoyance at my/my brother (sister) when he (she) aggravates me, messes with my stuff, etc. - and 38 - I manage to control my anger when my brother (sister) irritates me in some way - it is possible that the adolescents who had no siblings had difficulty imagining this particular interpersonal situation. With regard to item 17 - "I talk about sex with my parents" - the descriptive analyzes indicated that the majority of the adolescents $(57.8 \%)$ presented a low frequency of occurrence (between 0 and 4 times) in this item, indicating difficulty in performing this social skill. This value was discrepant in relation to the other social skills of the Social Resourcefulness factor, most of them with a frequency of occurrence between 3 and 4 times, thus influencing the validity and reliability of this item. For this reason, and considering the importance of these social skills in the adolescence (Barbosa Filho et al., 2012; D'Abreu \& Marturano, 2010; Goodman et al., 2010; Gresham et al., 2004; Murta et al., 2013; Salvo, 2010), it was decided to retain these items in the inventory.

The majority of the items of the IHSA-Del-Prette presented adequate factor loadings in their respective factors, which allows the comprehensive use of the separate factors. The results support the factorial validity and the reliability of the IHSA-Del-Prette (IHSA-Del-Prette-Manual sample between $\alpha=0.68$ and $\alpha=0.82$ and IHSA-Del-Prette-Conf sample between 
$\alpha=0.70$ and $\alpha=0.82$; CR between 0.70 and 0.82 ) This values are close to what is considered as an indicator of adequate reliability and Composite Reliability of the construct (Marôco, 2010).

In summary, this study confirmed the construct validity of the IHSA-Del-Prette, and indicated, through CFA, better indicators of internal consistency than those obtained, through PCA, in the original study. The instrument showed good psychometric qualities for adolescents in the Brazilian context, demonstrating a stable structure, which allows the Social Skills construct to be assessed in line with what was theoretically proposed. Considering the potential of the instrument evaluated, future studies could further investigate the cross-cultural invariance of the IHSA-Del-Prette, as well as refine the comprehension regarding gender, producing more evidence for the validity of the instrument.

Considering the problem guiding this study, it is reasonable to state that the IHS-Del-Prette is a valid and reliable resource for use in research and practice of social skills evaluation. In addition, the similarity of its structure of items, as obtained by CPA EFA and then confirmed by CFA, allows to sustain that the previous studies with IHSA-Del-Prette are not compromised by being based on its principal component structure. However, considering the cumulative nature of the validity evidence for any psychometric instrument, it is understood that further studies and methodological care with the quality of evaluations in this area are desirable and cannot be disregarded.

\section{Conclusion}

Despite the good psychometric indicators obtained for the IHSA-Del-Prette, some limitations of this study should be considered. Participants were assessed by convenience, providing a non-representative sample of the Brazilian population. The psychometric property results relate to a determined sample, not to the instrument per se. Given the cultural diversity of Brazil, it would be interesting if the IHSA-Del-Prette was applied with samples from different Brazilian regions, in order to expand its normative basis (or to define the different normative standards for each region). The cross-sectional and correlational design should also be considered, as this prevents cause and effect relationships from being established. Furthermore, the fact that the sample was composed of volunteers should also be considered. Finally, the similarities and differences between the demographic indicators verified in this sample and the sample of the IHSA-DelPrette Manual should be considered in the range of the results. Despite these limitations, the results indicate that the IHSA-Del-Prette is a useful psychological instrument for assessment and intervention studies that focus on the interpersonal repertoire of adolescents in the Brazilian context.

\section{Referências}

Achenbach, T. M. \& Rescorla, L. A. (2001). Manual for the ASEBA School-Age Forms and Profiles. Burlington, VT: University of Vermont, Research Center for Children, Youths and Families.

Anastasi, A. \& Urbina, S. (1997). Psychological Testing (7ํㅡㄹ. ed. New York, NY: Prentice Hall.

Arbuckle, J. L. (2008). Amos 17 users'guide. Chicago, IL: SPSS.

Associação Brasileira de Empresas de Pesquisa [ABEP] (2011). Dados com base no Levantamento Socioeconômico de 2009. Recuperado de $<$ http://www.abep.org/novo/Content.aspx?ContentID=302>.

Barbosa Filho, V. C., Campos, W., \& Lopes, A. S. (2012). Prevalence of alcohol and tobacco use among Brazilian adolescents: A systematic review. Revista Saúde Pública, 46(5), 901-917. http://dx.doi.org/10.1590/S003489102012000500018

Barkin, S. L., Smith, K. S., \& Durant, R. H. (2002). Social skills and attitudes associated with substance use behaviors among young adolescents. Journal of Adolescent Health, 20, 448-454. http://dx.doi.org/10.1016/S1054139X(01)00405-0

Caballo, V. E., Del Prette, Z. A. P., Monjas, I., \& Carrillo, G. (2006). La evaluación de las habilidades sociales en la vida adulta. In V. E. Caballo (Org.), Manual para la evaluación cognitivo-conductual de los trastornos psicológicos (pp. 401-420). Madrid: Pirámide.

Campos, J. R. (2014). Habilidades sociais de adolescentes com e sem indicadores de depressão, considerando análises de gênero. Manuscrito não publicado. Universidade Federal de São Carlos, São Carlos, Brasil.

Chen, K. (2006). Social skills intervention for students with emotional/behavioral disorders: A literature review from the American perspective. Educational Research and Reviews, 1(3), 143-149.

D’Abreu, L. C. F. \& Marturano, E. M. (2010). Associação entre comportamentos externalizantes e baixo desempenho escolar: Uma revisão de estudos prospectivos e longitudinais. Estudos de Psicologia, 15(1), 43-51. http://dx.doi. org/10.1590/S1413-294X2010000100006 
Del Prette, Z. A. P. \& Del Prette, A. (2001). Psicologia das habilidades sociais: Terapia, Educação e Trabalho (2⿳亠丷厂 ed.). Petrópolis: Vozes.

Del Prette, Z. A. P. \& Del Prette, A. (2005). Psicologia das habilidades sociais na infância: Teoria e prática. Petrópolis: Vozes.

Del Prette, Z. A. P. \& Del Prette, A. (2006). Psicologia educacional, forense e com adolescente em risco: Prática na avaliação e promoção de habilidades sociais. Avaliação Psicológica, 5(1), 99-104.

Del Prette, A. \& Del Prette, Z. A. P. (2009). Inventário de Habilidades Sociais para Adolescentes (IHSA-Del-Prette): Manual de aplicação, apuração e interpretação. São Paulo: Casa do Psicólogo.

Del Prette, Z. A. P. \& Del Prette, A. (2010/2012). Social skills and behavior analysis: Historical proximity and new issues. Perspectivas em Análise do Comportamento, 1(2), 104-115. (English version of a Portuguese paper originally published in 2010).

Del Prette, Z. A. P., Falcone, E. M. O., \& Murta, S. G. (2013). Contribuições do campo das habilidades sociais para a compreensão, prevenção e tratamento dos transtornos de personalidade. In L. F. Carvalho \& R. Primi (Orgs.), Perspectivas em psicologia dos transtornos da personalidade: Implicações teóricas e práticas (pp. 326-358). São Paulo: Casa do Psicólogo.

Del Prette, Z. A. P., Rocha, M. M., Silvares, E. F. M., \& Del Prette, A. (2012). Social skills and psychological disorders: Converging and criterion-related validity for YSR and IHSA-Del-Prette in adolescents at risk. Universitas Psychologica, 11(3), 941-955.

Del Prette, Z. A. P., Teodoro, M., \& Del Prette, A. (2014). Social skills of adolescents: Convergent validity between IHSA-Del-Prette and MESSY. Estudos de Psicologia (PUCCAMP), 31(1), 15-24. http://dx.doi.org/10.1590/0103166X2014000100002

Durlak, J. A., Weissberg, R. P., \& Pachan, M. (2010). A meta-analysis of after-school programs that seek to promote personal and social skills in children and adolescents. American Journal of Community Psychology, 45, $294-309$. http://dx.doi.org/10.1007/s10464-010-9300-6

Fraser, M. W. \& Williams, S. A. (2004). Aggressive behavior. In L. A. Rapp-Paglicci, C. N. Dulmus, \& J. S. Wodarski (Orgs.), Handbook of preventive interventions for children and adolescents (pp. 100-129). New Jersey: John Willey \& Sons.

Goldberg-Lillehoj, C. J., Spoth, R., \& Trudeau, L. (2005). Assertiveness among young rural adolescents: Relationship to alcohol use. Journal of Child \& Adolescent Substance Abuse, 14, 39-68. http://dx.doi.org/10.1300/J029v14n03_03

Goodman, S. H., Rouse, M. H., Connell, A. M., Broth, M. R., Hall, C. M., Heyward, D. (2010). Maternal depression and child psychopathology: A meta-analytic review. Clinical Child and Family Psychology Review, 14, 1-27. http:// dx.doi.org/10.1007/s10567-010-0080-1

Gresham, F. M., Cook, C. R., Crews, S. D., \& Kern, L. (2004). Social skills training for children and youth with emotional and behavioral disorders. Behavioral Disorders, 30(1), 32-46.

Hu, L. T. \& Bentler, P. M. (1999). Cutoff criteria for fit indexes in covariance structure analysis: Conventional Criteria versus new alternatives. Structural Equation Modeling, 6, 1-55. http://dx.doi.org/10.1080/10705519909540118

International Test Commission (ITC) (2014) ITC Guidelines on Quality Control in Scoring, Test Analysis, and Reporting of Test Scores. International Journal of Testing, 14(3), 195-217. http://dx.doi.org/10.1080/15305058.2014.918040

Kline, R. B. (2011). Principles and Practice of Structural Equation Modeling (3ae ed.). New York, NY: Guilford Press.

Leme, V. B. R. (2013). Adolescentes de famílias nucleares, monoparentais e recasadas: relações entre práticas parentais, habilidades sociais, bem-estar psicológico e percepção de apoio social. Relatório de Pesquisa não publicado, Universidade Federal de São Carlos, São Carlos, Brasil.

Marôco, J. (2010). Análise de Equações Estruturais: Fundamentos Teóricos, Software \& Aplicações. Pêro Pinheiro: Report Number, Lda.

Masten, A. M. \& Tellegen, A. (2010). Resilience in developmental psychopathology: Contributions of the Project Competence Longitudinal Study. Development and Psychopathology, 24, 345-361. http://dx.doi.org/10.1017/ S095457941200003X

Murta, S. G., Santos, B. R. P., Martins, C. P. S., \& Oliveira, B. (2013). Prevenção primária à violência no namoro: Uma revisão de literatura. Contextos Clínicos, 6(2), 117-131. http://dx.doi.org/10.4013/ctc.2013.62.05

Obradovic, J., Burt, K. B., \& Masten, A. S. (2010). Testing a dual cascade model linking competence and symptoms over 20 years from childhood to adulthood. Journal of Clinical Child and Adolescent Psychology, 39, 90-102. http:// dx.doi.org/10.1080/15374410903401120

Pilati, R. \& Laros, J. A. (2007). Modelos de equações estruturais em psicologia: Conceitos e aplicações. Psicologia: Teoria e Pesquisa, 23(2), 205-216. http://dx.doi.org/10.1590/S0102-37722007000200011

Rocha, M. M. (2012). Evidências de validade do Inventário de Autoavaliação para Adolescentes (YSR/2001) para a população brasileira. Tese de Doutorado, Universidade de São Paulo, SP. http://dx.doi.org/10.11606/t.47.2012.tde$12062012-153735$

Salvo, C. G. De. (2010). Práticas educativas parentais e comportamentos de proteção e risco à saúde na adolescência. Tese de Doutorado. Universidade de São Paulo, São Paulo, SP.

Sass, D. A. \& Schmitt, T. A. (2010). A comparative investigation of rotation criteria within exploratory factor analysis. Multivariate Behavioral Research, 45(1), 73-103. http://dx.doi.org/10.1080/00273170903504810 
Schweizer, K. (2010). Some guidelines concerning the modeling of traits and abilities in test construction. European Journal of Psychological Assessment, 26(1), 1-2. http://dx.doi.org/10.1027/1015-5759/a000001

Tabachnick, B. G. \& Fidell, L. S. (2007). Using Multivariate Statistics (5ae ed.). New York: Allyn and Bacon.

Worthington, R. L. \& Whittaker, T. A. (2006). Scale development research a content analysis and recommendations for best practices. The Counseling Psychologist, 34, 806-838. http://dx.doi.org/10.1177/0011000006288127

Autores:

Vanessa Barbosa Romera Leme - Doutora, Universidade do Estado do Rio de Janeiro.

Josiane Rosa Campos - Doutora, Universidade Estadual Paulista “Júlio de Mesquita Filho", São Paulo.

Susana Coimbra - Doutora, Universidade do Porto.

Almir Del Prette - Doutor, Universidade Federal de São Carlos.

Zilda Aparecida Pereira Del Prette - Doutora, Universidade Federal de São Carlos.

Endereço para correspondência:

Vanessa B. R. Leme

Rua Edmundo March, no 20, apto. 201 - Boa Viagem

24210-330 Niterói, RJ, Brasil

<vanessaromera@gmail.com>

Recebido em: 01.06.15

Aceito em: 14.06.16 